\title{
Characterization of a natural hemolysin in the serum of a hermit crab Clibanarius longitarsus (Crustacea: Decapoda)
}

\author{
M. Shanmughavalli ${ }^{1}$ and M. Arumugam ${ }^{2}$ \\ ${ }^{1}$ Department of Advanced Zoology \& Biotechnology, Quaid-E-millat govt. college (W), Chennai-600 002, India \\ ${ }^{2}$ Department of Zoology, University of Madras, Guindy Campus, Chennai-600 025, India
}

shanmughavalli@yahoo.com

\begin{abstract}
A naturally occurring hemolysin $(\mathrm{HL})$ was detected in the serum of the hermit crab Clibanarius longitarsus using mammalian RBC as indicator cells. The serum gave the highest $\mathrm{HL}$ titer with rabbit RBC. Cross adsorption of $C$. longitarsus serum with fixed rabbit RBC resulted in the complete removal of the lytic activity from the serum. The hemolytic activity in the serum of $C$. longitarsus was independent of divalent cations, reversibly sensitive to EDTA, thermolabile, stable between the $\mathrm{pH}$ 6-8. Further studies demonstrated that the $\mathrm{HL}$ activity is proteinaceous as it was precipitable by conventional deproteinizing agents and susceptible to the action of proteases and 2-mercapthoethanol. The HL-inhibition assay performed with several carbohydrates (mono, di, oligo, polysaccharides and Lipo polysaccharides) revealed that the serum $\mathrm{HL}$ was capable of specifically recognizing laminarin (a homopolymer of $\beta 1$, 3-glucan). Thus this hemolysin appears to be unique among all the known crustacean hemolysins.
\end{abstract}

Keywords: Hemolysin, serum, Clibanarius longitarsus, laminarin.

\section{Introduction}

The recent developments in intensive aquaculture practices have led to the outbreak of diseases in cultivable organisms, for the prevention of which the thorough knowledge of the invertebrate immune mechanism is essential. This has provided additional impetus and vigour to research on the mechanisms of immunity in invertebrates and has brought to light the presence of definitive immune reactions exhibiting a considerable degree of specificity and anamnestic quality involving both humoral and cellular component (Sindermann, 1971; Karp \& Rhein, 1980; Cooper et al., 1992; Osada et al., 1993).

The cellular defense reactions in invertebrates primarily include coagulating, phagocytic encapsulating, nodule forming entrapment and cytotoxic reponses depending on the size, number and nature of the invading foreign organism (Ratcliffe et al., 1985). Invertebrate serum although lacking immunoglobulins has a range of factors which mediate lytic, agglutinating, cytotoxic and antimicrobial activities against various biological reagents. These factors may be naturally occurring or formed after antigenic stimulation. These factors involve in invertebrate defence reactions include lysins, agglutinins, bactericidins, lymphokine-like substances Prophenol oxidase cascade system and lipo polysaccharide binding proteins. Among these components, lysins which are referred to as hemolysins or cytotoxic molecules or killing factors have been reported infrequently and they have tended to receive rather less scrutiny (Smith \& Chisholm, 1992).

In invertebrates lysis of invading microbial and macrobial parasites is primarily brought about by the components of complement system. The presence of lytic activity has been demonstrated in a wide range of invertebrates and investigation into the lytic system of invertebrates has concentrated chiefly on their ability to lyse vertebrate erythrocytes in vitro. Lysins are thought to play an important role as serum factors in the immune mechanism of invertebrates (Osada et al., 1993). There are a few reports based on in vitro and in vivo experiments suggested the possible role of lysins in immune mechanisms. In invertebrates it has been suggested that carbohydrates and lipids on the membrane of targets may be specifically recognised by the hemolysin. In the present study hemolytic activity of the serum of hermit crab Clibanarius longitarsus was tested for its ability to cause lysis of RBCs, the physicochemical properties and binding specificity.

\section{Materials and methods \\ Experimental animals and laboratory maintenance}

The hermit crab Clibanarius longitarsus were collected from Royapuram, sea shore, Chennai. Both male and female hermit crabs were brought to the laboratory. These were maintained in plastic tanks containing marine water and the medium was changed every day. Only healthy uninjured hermit crabs weighing 8.4 to $12.6 \mathrm{~g}$ were used.

Preparation of serum

The hemolymph was withdrawn by inserting the needle of a syringe in to the arthrodial membrane connecting the leg and the abdomen region. The samples were collected in polystyrene tubes held on ice and allowed to clot at room temperature (RT) $(28 \pm 2 \mathrm{C})$ for 20 $\mathrm{min}$. It was centrifuged $(400 \times \mathrm{g}, 10 \mathrm{~min}$ at RT) and the
Research article

CIndian Society for Education and Environment (iSee)
"Natural humolysin from hermit crab" http://www.indjst.org
Shanmughavalli \& Arumugam Indian J.Sci.Technol. 
resulting clear supernatant $(=$ serum $)$ was used immediately.

\section{Preparation of erythrocyte (RBC) suspension}

Human and other mammalian blood samples were obtained by venous or cardiac puncture and collected in sterile Alsever's solution (Gravey et al., 1979) containing $10 \mu \mathrm{g} / \mathrm{ml}$ of streptomycin. Prior to use, the RBCs were washed thrice with $0.9 \%$ saline and once with TBS-II (50 $\mathrm{mM}$ tris- $\mathrm{HCl}, 115 \mathrm{mM} \mathrm{NaCl}, 10 \mathrm{mM} \mathrm{CaCl}_{2}(300 \mathrm{mOsm})$ ) by centrifugation ( $400 \times \mathrm{g}, 5 \mathrm{~min}$ at RT). Unless specified, the RBC pellet was finally resuspended in TBS-II as $1.5 \%$ suspension (v/v).

\section{Hemolytic (HL) assay}

$\mathrm{HL}$ assay were performed in V-bottom microtiter plates (Greiner, Nurtingen, Germany) by serial two-fold dilution of a $25 \mu \mathrm{l}$ of serum sample with an equal volume of TBS-II. After dilution, $25 \mu \mathrm{l}$ RBC suspensions was added to each well and incubated for $30 \mathrm{~min}$ at RT. The $\mathrm{HL}$ titers were recorded as the reciprocal of the highest dilution of the sample causing complete lysis of RBC (Garvey et al., 1979). Controls for all assays consisted of the substitution of the sample by TBS-II. All the HL assays were performed in duplicate serum samples.

\section{Determination of percentage hemolysis}

$100 \mu \mathrm{l}$ of sample was mixed with an equal volume of $1.5 \%$ RBC suspension. Incubated at RT for $30 \mathrm{~min}$, centrifuged at $400 \times \mathrm{g}, 5 \mathrm{~min}$ at RT. A known amount of supernatant solution was diluted 10 fold using TBS-II and the amount of hemoglobin release was determined at 541 $\mathrm{nm}$ on a Shimadzu UV-160A spectrophotometer.

$\%$ hemolysis $=\underline{\text { Test release }- \text { Spontaneous release }} \times 100$ Maximum release

Maximum release was obtained with double distilled water, spontaneous release was obtained with TBS-II.

\section{Cross absorption tests}

Serum samples $(300 \mu l)$ were mixed with an equal volume of washed and packed rabbit RBC and incubated for $1 \mathrm{hr}$ at RT with occasional shaking. The suspension was centrifuged, supernatant collected and absorbed for a second and third time under the same conditions. The serum adsorbed thrice was subsequently tested for $\mathrm{HL}$ activity against fresh RBC types (Human A, B, O, Sheep and Rabbit RBC).

\section{Cation dependency and EDTA sensitivity}

Serum samples $(500 \mu \mathrm{ll})$ were dialysed (M W exclusion limit $<10,000$ ) extensively with TBS-II (to test cation dependency) or TBS-V (50 mM tris- $\mathrm{HCl}, 100 \mathrm{mM}$ $\mathrm{NaCl}, 50 \mathrm{mM}$ EDTA (300 Osm) to examine EDTA sensitivity at $17^{\circ} \mathrm{C}$. The samples dialysed against TBS-V were subsequently re-equilibrated by dialysis against TBS-I (50 mM tris- $\mathrm{HCl}, 135 \mathrm{mM} \mathrm{NaCl}(300$ mOsm)). The resulting dialysates were centrifuged and the remaining $\mathrm{HL}$ activity in the supernatant was determined using rabbit RBC (RRBC) in the presence of TBS that did or did not contain $10 \mathrm{mM} \mathrm{CaCl} 2, \mathrm{MgCl}_{2}$, or $\mathrm{MnCl}_{2}$. A serum sample, concurrently dialysed against TBS-II, was also tested for its HL activity against RRBC in TBS-II.
Vol. 4 No. 5 (May 2011)

ISSN: 0974- 6846

\section{$\mathrm{pH}$ and thermal stability}

The stability of $\mathrm{HL}$ activity in different $\mathrm{pH}$ was examined by dialyzing (24 hrs, 17C) $300 \mu \mathrm{l}$ serum samples against the following buffers at $\mathrm{pH}$ ranging from 3 to 12 (Lillie, 1954; Pearse, 1968), $0.2 \mathrm{M}$ acetate buffer $(\mathrm{pH} 3$ to 6$), 0.2 \mathrm{M}$ tris- $\mathrm{HCl}$ buffer $(\mathrm{pH} 7$ to 9$)$ and $0.1 \mathrm{M}$ glycine $\mathrm{NaOH}$ buffer (pH 10 to 12). After dialysis, all the samples were finally re-equilibrated by dialysis against TBS-II, and the HL titer determined with RRBC. In another experiment designed to study the thermal stability of $\mathrm{HL}, 300 \mu \mathrm{l}$ serum samples were held for 30 $\mathrm{min}$ at temperatures ranging from 10 to $100 \mathrm{C}$, centrifuged and tested for the remaining $\mathrm{HL}$ activity with RRBC.

\section{Precipitation, susceptibility to proteases and 2- mercaptoethanol (2-ME)}

Precipitation of $\mathrm{HL}$ activity from serum was attempted using $20 \%, 40 \%, 60 \%$ and $80 \%$ ammonium sulphate $\left[\left(\mathrm{NH}_{4}\right)_{2} \mathrm{SO}_{4}\right]$ solutions as well as $10 \%$ trichloro acetic acid (TCA). The HL activity was finally measured using RRBC. Susceptibility of serum HL to exogenous proteases was studied using trypsin at a final enzyme concentration of $20 \mathrm{mg} / \mathrm{ml}$. The serum-enzyme mixtures were incubated up to $3 \mathrm{hrs}$ at $26 \mathrm{C}$. Controls consisted of serum and heatinactivated (at $100 \mathrm{C}, 10 \mathrm{~min}$ ) enzyme. The samples collected immediately or after 3 hrs incubation were centrifuged and the supernatants were tested for $\mathrm{HL}$ activity using RRBC.

To test the effect of 2-ME, a reducing agent on $\mathrm{HL}$ activity, diluted serum samples were treated with 2-ME at a final concentration of $0.4 \mathrm{M}$ up to $4 \mathrm{hrs}$ at $37 \mathrm{C}$ and then dialysed extensively against TBS-II to remove 2-ME. The samples before and after dialysis were tested for $\mathrm{HL}$ activity using RRBC.

$H L$ - inhibition assays

Several carbohydrates (mono, di, oligo, polysaccharides and Lipo polysaccharides) were tested for ability to inhibit serum HL activity. They were dissolved in TBS-II and if necessary, the $\mathrm{pH}$ was adjusted to 7.5 using concentrated $\mathrm{NaOH}$. Serum samples were diluted with TBS-II to a HL titer of 4 against RRBC. The inhibitor to be tested $(25 \mu \mathrm{l})$ was serially diluted two-fold with an equal volume of diluted sample in microtiter plates and incubated for $1 \mathrm{~h}$ at RT. RRBC suspension (25 $\mu$ l) was added to each well and kept for $30 \mathrm{~min}$ at RT. The minimal concentration of carbohydrate that completely inhibited HL activity was recorded.

\section{Results}

\section{Serum HL profile}

The serum of hermit crab $C$. longitarsus possess a natural hemolysin capable of lytic activity against various mammalian red blood corpuscles (RBC). Among the various $R B C$ types tested, rabbit RBC was found to be the most susceptible target cell, (lytic titer: 64) compared to human A, B, O and sheep RBCs. On the other hand, serum hemolytic titer against ox, buffalo, goat and rat was not detectable. However, the percentage lysis calculated 
spectrophotometrically for these RBCs showed range of 25.6 to $48.8 \%$ (Table1).

Table1. Hemolytic activity of Clibanarius longitarsus serum against various mammalian erythrocyte types

\begin{tabular}{|l|c|c|}
\hline RBC Types & \% Hemolysis & Hemolytic titer \\
\hline Rabbit & 76.2 & 64 \\
Human O & 71.1 & 16 \\
Human B & 69.9 & 16 \\
Human A & 65.5 & 16 \\
Sheep & 55.9 & 8 \\
Buffalo & 45.5 & 0 \\
Rat & 25.6 & 0 \\
ox & 48.8 & 0 \\
goat & 42.5 & 0 \\
\hline
\end{tabular}

Based on 5 determinations for each RBC type and the data for \% hemolysis represent the mean and the hemolytic titer represents median values

\section{Cross adsorption tests}

Cross adsorption tests using rabbit RBC was carried out to check whether the hemolytic activity observed against various RBC types was caused by a single fraction or multiple fractions. Rabbit RBC was used for cross adsorption test after being fixed in formalin to prevent lysis. Adsorption of diluted serum with formalin fixed rabbit RBC resulted in the complete removal of hemolytic activity against human A, B, O and sheep RBCs (Table 2).

Table 2. Cross adsorption of Clibanarius longitarsus serum hemolytic activity with rabbit erythrocyte

\begin{tabular}{|c|c|c|c|c|}
\hline \multirow{2}{*}{$\begin{array}{c}\text { RBC } \\
\text { types } \\
\text { tested }\end{array}$} & \multicolumn{3}{|c|}{ Serum absorbed with } \\
\cline { 2 - 5 } & $\begin{array}{c}\text { Hemolytic } \\
\text { titer }\end{array}$ & $\begin{array}{c}\% \\
\text { Hemolysis }\end{array}$ & $\begin{array}{c}\text { Hemolytic } \\
\text { titer }\end{array}$ & $\begin{array}{c}\% \\
\text { Hemolysis }\end{array}$ \\
\hline Rabbit & 16 & 77.7 & 0 & 0 \\
\hline $\begin{array}{c}\text { Human } \\
\text { A }\end{array}$ & 04 & 71.5 & 0 & 0 \\
\hline $\begin{array}{c}\text { Human } \\
\text { B }\end{array}$ & 04 & 70.1 & 0 & 0 \\
\hline $\begin{array}{c}\text { Human } \\
\text { O }\end{array}$ & 04 & 70.5 & 0 & 0 \\
\hline Sheep & 02 & 52.2 & 0 & 0 \\
\hline
\end{tabular}

Based on 5 determinations and the data of hemolytic titer and $\%$ hemolysis represent median and mean values respectively.

\section{Cation dependency and EDTA sensitivity}

It was observed that the assay of serum hemolytic activity in the presence of $\mathrm{Ca}^{2+}$, dialysed against TBS-II remained unaffected as compared to that of undialysed serum. In the samples dialysed against TBS alone or dialysed against TBS- $V$ followed by redialysis against TBS alone, the hemolytic activity was unaffected only in the presence of $\mathrm{Ca}^{2+}$, whereas the absence of any cations and in the presence of $\mathrm{Mg}^{2+}$ or $\mathrm{Mn}^{2+}$ the hemolytic activity was reduced by 1 well as compared to that of undialysed serum (Table 3 ).

\section{The $\mathrm{pH}$ and thermal stability}

The hemolytic activity was stable between $\mathrm{pH}$ of 6 to 8. The $\mathrm{pH}$ tested below or above this range the hemolytic activity was distinctly lower and totally lost at pH 11 to 12 . The activity remained stable between $36 \mathrm{C}$ to $40 \mathrm{C}$ and decreased at temperatures tested above and below this range. Noticeably, all hemolytic was lost at $60 \mathrm{C}$ and above.

\section{Precipitation, susceptibility to proteases and 2-ME}

Both ammonium sulphate at $40 \%$ saturation as well as TCA at $10 \%$ precipitated all $\mathrm{HL}$ activity from serum. Incubation of serum with trypsin immediately reduced the hemolytic titer. No hemolytic activity could be detected in samples incubated for $2 \mathrm{hrs}$ with trypsin. The treatment of serum with 2-ME $(0.2 \mathrm{M})$ reduced the hemolytic titer and this reduced activity did not change after removal of 2-ME by dialysis.

\section{Binding specificity of serum hemolysin}

Out of 52 carbohydrates, 6 glycoproteins and 2 LPS tested only laminarin a homopolymer of $\beta 1,3$-glucan inhibited the serum hemolytic activity at a minimum concentration of $0.5 \%$.

\section{Discussion}

The serum of the hermit crab $C$. longitarsus possesses naturally occurring hemolytic activity which showed the highest reactivity with RRBC among other RBC types tested. In addition, the hemolysis of mammalian RBCs at varying degrees, indicate a differential affinity of the hemolysin molecules for different mammalian RBCs. Cross adsorption of $C$. longitarsus serum with fixed rabbit RBC resulted in the complete removal of the lytic activity (both percentage lysis and hemolytic titer) from the serum, suggesting the presence of a single hemolysin fraction, with varying degree of specificity, responsible for the lytic activity observed against rabbit, human $A, B, O$ and sheep erythrocytes.

The hemolytic titer of the serum dialysed against TBS alone was reduced by one well in the absence of cations and in the presence of $\mathrm{Mg}^{2+}$ or $\mathrm{Mn}^{2+}$ but in the presence of $\mathrm{Ca}^{2+}$ the hemolytic titer was restored to the level observed for undialysed serum and serum dialysed in TBS-II. Thus, the hemolytic activity in the serum of C. longitarsus was independent of divalent cations, in contrast to the hemolysins which have largely been reported to be cation dependant as in the case of echinoderms and tunicates (Canicatti and Parrinello, 1985; Canicatti, 1987; Canicatti and Ciulla, 1988; Canicatti, 1989; Perrinello et al., 1993). In addition, Weinheimer et al., (1969) have reported that the serum hemolysin of spiny lobster $P$. argus was stable up to 7 days in the presence of $\mathrm{Ca}^{2+}$ and $\mathrm{Mg}^{2+}$ and the hemolytic activity was inactivated by EDTA.

However, in the present investigation it was observed that the hemolytic activity in the serum of $C$. longitarsus was only partially susceptible to EDTA, since the serum dialysed against EDTA retained most of the hemolytic activity even in the absence of any cations and in the 
Indian Journal of Science and Technology

Table 3. Effect of divalent cations and EDTA on hemolytic activity of Clibanarius longitarsus serum

\begin{tabular}{|l|c|c|c|}
\hline Serum sample tested & $\begin{array}{c}\text { Cation (10 mM) in } \\
\text { diluting medium as } \\
\text { well as in } \mathrm{RBC} \\
\text { suspension }\end{array}$ & $\begin{array}{c}\text { Hemolytic } \\
\text { titer }\end{array}$ & $\begin{array}{c}\text { Hemolysis } \\
(\%)\end{array}$ \\
\hline Before dialysis & $\begin{array}{c}\text { None } \\
\mathrm{CaCl}_{2}\end{array}$ & 4 & 70.1 \\
\hline After dialysis against TBS+ & & 8 & 72.3 \\
$10 \mathrm{mM} \mathrm{CaCl}_{2}$ (pH 7.5) & $\mathrm{CaCl}_{2}$ & 8 & 82.2 \\
\hline After dialysis against TBS & $\mathrm{None}$ & 4 & 74.9 \\
alone (pH 7.5) & $\mathrm{CaCl}_{2}$ & 8 & 77.8 \\
\hline After dialysis against TBS+ & $\mathrm{MgCl}_{2}$ & 4 & 70.4 \\
50 mM EDTA followed by & $\mathrm{None}_{2}$ & 4 & 69.3 \\
redialysis against TBS & $\mathrm{CaCl}_{2}$ & 8 & 73.9 \\
alone (pH 7.5) & $\mathrm{MgCl}_{2}$ & 4 & 69.1 \\
& $\mathrm{MnCl}_{2}$ & 4 & 63.8 \\
\hline
\end{tabular}

Determinate using rabbit $R B C$ based on 5 determinations and the data for $\%$ hemolysis and hemolytic titer represent the mean and median values respectively.

presence of $\mathrm{Mg}^{2+}$ or $\mathrm{Mn}^{2+}$, the loss in hemolytic activity could be recovered in the presence of $\mathrm{Ca}^{2+}$. These observations clearly indicate that the hemolytic activity in the serum of $C$. longitarsus was reversibly sensitive to EDTA and independent of cations, though maximum activity could be observed in the presence of $\mathrm{Ca}^{2+}$.

The hemolytic activity in invertebrates has been reported to be thermolabile (Dales, 1982; Canicatti, 1987 \& 1989; Leippe and Renwrantz, 1988), and the results obtained in the present investigation are in concordance with the above observation. Suggesting that, hemolytic activity observed in the serum of $C$. longitarsus was temperature dependent and may be enzymatic in nature. When dialysed against buffers of varying $\mathrm{pH}$ the hemolytic activity in the serum of $C$. longitarsus was found to be stable between the $\mathrm{pH}$ ranges $6-8$, and drastically affected at $\mathrm{pH}$ relatively lower or higher than this range. This observation is in conformity with the report of Kisugi et al (1992) on the cytolytic factor in the whole body homogenate of $C$. longitarsus. The crustacean lytic principles are active only in a narrow range of $\mathrm{pH}$.

A major part of the hemolytic activity in the serum of the hermit crab $C$. Iongitarsus was precipitable by $40 \%$ saturated ammonium sulphate and $10 \%$ TCA completely precipitated the hemolytic activity, indicating the proteinaceous nature of the hemolytic molecule. This suggestion gains further confirmation, from the fact that treatment of serum with trypsin (a protease) which is known to cleave the proteins specifically between the lysine-arginine residues (Lehninger, 1970), results in the complete loss of hemolytic activity. In this connection it may be noted that the hemolysin from the coelomic fluid of annelids and echinoderms (Parrinello et al., 1979; Roch, 1979;Roch et al., 1981; Canicatti, 1987; Osada et
Vol. 4 No. 5 (May 2011)

ISSN: 0974- 6846

al., 1993), the cytolytic factor from hemocyte of the bivalve Corbicula fluminea and Mytilus edulis (Yoshino \& Tailan Tuan, 1985; Leippe \& Renwrantz, 1988) are reported to be proteinaceous in nature. The present study indicates that the serum hemolytic factor in the hermit crab $C$. longitarsus is proteinaceous in nature.

The treatment of serum with $\beta$ mercaptoethanol, which is known to cleave the disulphide bonds, resulted in the loss of hemolytic activity within one hour; this effect could not be reversed upon removal of $\beta$ mercaptoethanol by dialysis. Thus indicating the presence of disulphide linkages on the molecule, and intact disulphide linkages are required for the activity. Studies on binding properties of hemolysin in annelids, molluscs and echinoderms (Decker et al., 1981; Roch et al., 1981; Dales, 1982; Cannicatti \& Parrinello, 1985; Cannicatti, 1987, 1989, 1991) have shown the hemolysins could specifically recognize sugars or phospholipids. In the present investigation, out of the wide range of sugars, glycoproteins and lipopolysaccharides tested, only laminarin a homopolymer of $\beta$ 1,3-glucan inhibited the hemolytic activity against rabbit RBC. Thus the present study constitutes the first report on the specific binding of a crustacean hemolysin to laminarin (an algal surface component), providing an insight into the molecular nature of hemolysin in host-defense in crustaceans.

From the results of the present investigation it may be concluded that the hemolysin of the serum of $C$. longitarsus is a unique cation independent homogenous protein with ability to cause lytic activity and capable of specifically recognizing laminarin (a homopolymer of $\beta 1$, 3-glucan).

\section{References}

1. Canicatti C (1987) Evolution of the lytic system in echinoderms. I. Naturally occurring hemolytic activity in Paracentrotus lividus (Echinoidea) coelomic fluids. Boll. Zool. 4, 325-329.

2. Canicatti C (1989) Evolution of the lytic system in echinoderms. II. Naturally occurring hemolytic activity in Marthasterias glacialis (Asteroidea) coelomic fluids. Comp. Biochem. Physiol. 93a, 587-591.

3. Canicatti C (1991) Binding properties of Paracentrotus lividus (Echinoidea) hemolysin. Comp. Biochem. Physiol. 98A, 463-468.

4. Canicatti C and Ciulla D (1988) Studies on Holothuria polii (Echinodermata) coelomocyte lysate. 11. isolation of coelomocyte hemolysins. Dev.Comp. Immunol. 12, 55-64.

5. Canicatti C and Parrinello N (1985) Hemagglutinin and hemolysin levels in the coelomic fluid from Holothuria polii (Echinodermata) following sheep erythrocyte. injection. Biol. Bull. 168, 175-1892. 
6. Cooper EL, Rinkevich B, Uhlenbruck $G$ and Valembois $P$ (1992) Invertebrate immunity:Another view point. Scand.J.Immunol. 35, 247-266.

7. Decker JM, Elmholt A and Muchmore (1981) Spontaneous cytotoxicity mediated by invertebrate mononuclear cells toward normal and malignant vertebrate targets: inhibition by defined mono- and disaccharides. Cell. Immunol. 59, 161-170.

8. Dales RP (1982) Hemagglutinins and hemolysins in the body fluids of Neoamphitrite figulus and Arenicola marina (Annelida: polychaeta).Comp. Biochem. Physiol. 73A, 663-667.

9. Garvey JS, Cremer NE and Sussdorf DH (1979) Methods in immunology p.545, W.A. Benjamin Inc., Reading, Massachusetts.

10. Karp RD and Rheins LA (1980) Induction of specific humoral immunity to soluble proteins in the American cockroach Periplaneta Americana. 11. Nature of the secondary response. Dev.Comp.Immunol. 4, 629639.

11. Kisugi J, Kamiya H and Yamasaki M (1992) Biopolymers of marine invertebrates xii. A novel cytolytic factor from a hermit crab, Clibanarius longitarsus. Chem.Pharm.Bull. 40(6), 1641-1643.

12. Lehninger AL (1970) Biochemistry, Worth Publishers Inc., NY. pp: 833.

13. Leippe $M$ and Renwrantz L (1988) Release of cytotoxic and agglutinating molecules by Mytilus hemocytes. Dev.Comp.Immunol.12, 297-308.

14. Lillie RD (1954) Histopathologic technique and practical histochemistry. The Blackiston Company Inc., NY. pp: 501.

15. Osada M, Ito T, Matsutani T and Mori K (1993) Partial purification and characterization of hemolysin from the coelomic fluid of Strongylocentrocentrotus nudus. Comp. Physiol. 105b, 43-49.

16. Parrinello N, Rindone D and Canicatti C (1979) Naturally occurring hemolytic system of the coelomic fluid of Holothuria polii Delle chiaie (Echinodermata). Dev. Comp. Immunol. 5, 33-42.

17. Parrinello N, Arizza V, Cammarata M and Parrinello DM (1993) Cytotoxic activity of Ciona intestinalis (Tunicata) hemocytes: Properties of the in vitro reaction against erythrocyte targets. Dev. Comp. Immunol. 17, 19-27.

18. Pearse AGE (1968) Histochemistry: Theoroetical and applied, Vol. I ( $3^{\text {rd }}$ edn.), Churcill Livingston. pp: 759.

19. Ratcliffe NA, Rowley AF, Fitzgerald SW and Rhodes CP (1985) Invertebrate immunity: Basic concepts and recent advances. Int. Rev. Cytol. 97, 183-350.

20. Roch P (1979) Protein analysis of earthworm coelomic fluid :1 polymorphic system of the natural hemolysin of Eisenia fetida Andrei. Dev. Comp. Immunol. 3, 599-608.

21. Roch $P$, Valembois $P$, Davant $N$ and Lassegues $M$ (1981) Protein analysis of earthworm coelomic fluid11. Isolation and biochemical characterization of the
Vol. 4 No. 5 (May 2011)

ISSN: 0974- 6846

Eisenia fetida Andrei factor (EFAF). Comp.Biochem. Physiol. 69B, 829-836.

22. Sindermann CJ (1971) Internal defence of crustacean: A review. Fish Bull. 69, 455-489.

23. Smith VJ and Chisholm JRS (1992) Non-cellular immunity in crustaceans. Fish \& Shellfish Immunol. 2, 1-31.

24. Weinheimer PF, Evans EE, Stroud RM, Acton RT and Painter B (1969) Comparative immunology : Natural haemolytic system of the spiny lobster Panulinurus argus. Proc. Exp. Biol. Med. 130, 322-326.

25. Yoshino TP and Tai-Lan Tuan (1985) Soluble mediators of cytolytic activity in hemocytes of the Asian clam Corbicula fluminea. Dev.Comp.Immunol. 9, 515-522.
"Natural humolysin from hermit crab" http://www.indjst.org
Shanmughavalli \& Arumugam Indian J.Sci.Technol. 